\begin{tabular}{|c|c|c|}
\hline 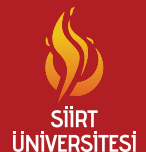 & $\begin{array}{c}\text { Türkiye Tarımsal Araştırmalar Dergisi } \\
\text { dergipark.gov.tr/tutad }\end{array}$ & $\begin{array}{l}\text { Turk J Agric Res } \\
\text { 2019, 6(1): 10-19 } \\
\text { ○ TÜTAD } \\
\text { ISSN: 2148-2306 } \\
\text { e-ISSN: 2528-858X }\end{array}$ \\
\hline Bilimin Psuända & Araştırma Makalesi / Research Article & doi: $10.19159 /$ tutad.430959 \\
\hline
\end{tabular}

\title{
Güneydoğu Anadolu Orijinli Yerel Makarnalık Buğday (Triticum durum Desf.) Genotiplerinin Bazı Tarımsal Karakterler Bakımından Değerlendirilmesi*
}

\author{
Fatih ÇIĞ $\breve{1 * *}^{* *}$ Mehmet KARAMAN ${ }^{2}$ \\ ${ }^{1}$ Siirt Üniversitesi, Ziraat Fakültesi, Tarla Bitkileri Bölümü, Siirt, TÜRKIYYE \\ ${ }^{2}$ Muş Alparslan Üniversitesi, Uygulamalı Bilimler Fakültesi, Bitkisel Üretim ve Teknolojileri Bölümü, Muş, TÜRKIYE
}

\begin{tabular}{ll}
\hline \multicolumn{1}{c}{ Geliş Tarihi/Received: 05.06 .2018} & Kabul Tarihi/Accepted: 31.12 .2018 \\
\hline ORCID ID (Yazar sırasina göre / by author order) & \\
\hline (Dorcid.org/0000-0002-4042-0566 (D) orcid.org/0000-0002-9008-4011 & \\
${ }^{* *}$ Sorumlu Yazar/Corresponding Author: fatih@siirt.edu.tr &
\end{tabular}

"Sorumlu Yazar/Corresponding Author: fatih@siirt.edu.tr

Öz: Bu çalışma; Güneydoğu Anadolu Bölgesi’ne ait bazı yerel makarnalık buğday (Triticum durum Desf.) genotiplerinin, bilinen modern ıslah edilmiş çeşitlerle kıyaslanarak bazı tarımsal özelliklerinin değerlendirilmesi amacıyla yürütülmüștür. Araştırmada, 21 adet yerel makarnalık genotipi ile 4 adet standart çeşit bitkisel materyal olarak kullanılmıştır. Çalışma, 2013-2014 ve 2014-2015 yılları yetiştirme sezonlarında, Mardin ili Kızıltepe ilçesinde yürütülmüştür. Kullanılan genotipler bazı morfolojik ve fizyolojik parametreler bakımından değerlendirilmiştir. İki yıllık ortalama verilere göre; incelenen özellikler açısından yıllar ve genotipler arasındaki farklılıklar istatistiki olarak çok önemli bulunurken, karakterlerin tümünde genotip x yıl interaksyonu önemsiz olarak tespit edilmiştir. Genotiplerin; tane verimi 201-347 kg da ${ }^{-1}$, metre karede başak sayıs1 190-349 adet $\mathrm{m}^{-2}$, başakta tane sayıs1 20.83-38.80 adet başak ${ }^{-1}$, başak uzunluğu 6.3-10.1 cm arasında değişmiştir. Fizyolojik parametre olarak kabul edilen normalize edilmiş vejetasyon indeksi (NDVi), klorofil miktarı (SPAD değeri), yaprak alan indeks (YAİ) değeri, bitki örtüsü sıcaklığı (BÖS) değerleri bakımından çeşitler arasında istatistiki olarak çok önemli farklılıklar tespit edilmiş; korelasyon analiz sonuçlarına göre tane verimi ile metrekarede başak sayısı ve biyolojik verim arasında, SPAD değeri ile biyolojik verim arasında, YAİ değeri ile SPAD ve NDVİ değerleri arasında istatistiki olarak önemli ve yüksek korelasyonlar tespit edilmiştir. Birim alanda başak sayısı, başakta tane sayısı ve biyolojik verim, tane verimini arttırmaya yönelik karakterler olarak belirlenirken, NDVİ, SPAD ve YAİ parametreleri ise biyolojik verime dolaylı olarak da tane verimine etki eden faktörler olarak tespit edilmiştir.

Anahtar Kelimeler: Yerel buğday, makarnalık buğday, fizyolojik karakterler, morfolojik karakterler

\section{Evaluation of Durum Wheat (Triticum durum Desf.) Genotypes Originated from Southeast Anatolia Region for Some Agricultural Character}

\begin{abstract}
This study was conducted to determine some agricultural properties of some local durum wheat (Triticum durum Desf.) genotypes, belonging to Southeast Anatolia Region, compared to modern cultivated varieties. In the study, 21 standard durum wheat genotypes and 4 standard varieties were used as plant material. The study was carried out in Kiziltepe district of Mardin province in 2013-2014 and 2014-2015 growing seasons. The genotypes used were evaluated for some morphological and physiological parameters. According to two-year average data; the differences between genotypes and years were found to be statistically significant, whereas genotype $\mathrm{x}$ year interaction was found to be insignificant in all of the characters. Grain yield ranged between 201-347 $\mathrm{kg} \mathrm{da}^{-1}$; spike number was 190-349 spike $\mathrm{m}^{-2}$; grain number per spike was 20.83-38.80 grain spike ${ }^{-1}$; and spike length was between $6.33-10.08 \mathrm{~cm}$, respectively. There were statistically significant differences between the varieties in terms of normalized vegetation index (NDVI), chlorophyll content (SPAD value), leaf area index (YAI) value, vegetation temperature (BOS) values which are accepted as physiological parameters. According to the results of correlation analysis, statistically significant and high correlations between grain yield (GY), number of spikes $\mathrm{m}^{-2}$ and biological yield (biomass), and between LAI value, SPAD value and NDVI values were found.
\end{abstract}

Keywords: Landrace wheat, durum wheat, physiological characters, morphological characters

": Bu çalışma; 27-29 Eylül 2017 tarihlerinde Bayburt’ta düzenlenen I. Uluslararası Organik Tarım ve Biyo-Çeşitlilik Sempozyumu'nda sözlü bildiri olarak sunulmuş olup, adı geçen kongrenin bildiriler kitabında özet metni yayınlanmıştır. 


\section{Giriş}

Makarnalık buğday (Triticum durum Desf.) Akdeniz iklimine sahip alanların geleneksel bitkisi olup; 10.000 y1l önce Verimli Hilal denilen ve Güneydoğu Anadolu Bölgesi'nin de içinde bulunduğu alanda kültüre alınmış, daha sonra Kuzey Akdeniz ve Kuzey Afrika ülkelerine yayılmıştır (Heun ve ark., 1997. Bu süreç doğal ve insan eliyle yapılan seleksiyonlar ile 20. yüzyıla kadar yoğun olarak yetiştirilen yerel buğdayların oluşumu ile sonuçlanmıştır. Yeşil Devrim olarak adlandırılan süreç içerisinde, buğday bitkisine kısa boyluluk genlerinin aktarılması, yoğun gübre ve tarım ilaçlarının kullanımı sonucunda yerel buğday çeşitlerinin yetiştiriciliği giderek azalmıştır. Günümüzde ise özellikle kuraklığın hakim olduğu ve tarımsal teknolojiden yoksun alanlarda yerel buğdayların tarımı devam etmiştir (Baloch ve ark., 2017). Ancak, yerel çeşitlerde genetik çeşitlilik giderek azalmış ve bazı çeşitler sadece tohum gen bankalarınđa muhafaza altına alınmıştır (Özkan ve ark., 2011). Kalite, tat ve aroma başta olmak üzere, bazı ticari karakterler bakımından yararlı özelliklere sahip bazı yerel çeşitler, özellikle sulamanın sınırlı olduğu yerlerde modern ıslah çeşitlerine göre tane verimi bakımından tatmin edici bir verim potansiyeline sahiptir (Aktaş, 2016). Aynı zamanda yerel çeşitlerde, sulama suyunun sinırlı olduğu ekolojik koşullarda az sayıda başaklanma ve bunu takiben hızlı bir tane olum süresi görülmektedir. Özellikle stres koşullarında da yerel çeşitler, gıda güvenliği açısından önemli bir potansiyele sahiptir. Bununla birlikte, yüzyıllar boyunca aynı bölgelerde sürekli yetiştirildiği için sarı pas gibi bazı hastalık ırkları da bu çeşitlerde epidemi yapabilmekte; fakat yerel çeşitlerdeki hastalığın gelişim süreci çok yavaş olmaktadır. Bu nedenle yerel çeşitler hastalığa karşı kısmi dayanıklılık (Partial resistanceslowrusting) mekanizmas1 sayesinde verim kayb1 en az düzeyde olduğu belirtilmektedir (Wan ve ark., 2004; Chen, 2005). Yerel buğday genotiplerinin uzun boylu olması nedeniyle özellikle kuru tarım arazilerinde saman miktarı açısından da bir avantaj sağlamaktadır. Bu durum hayvancılık açısından önemli olmasına rağmen genotiplerde görülen yatma nedeniyle istenmeyen bir özelliktir. Yetiştiricilikte uygulanan kültürel uygulamalar kontrollü şartlarda yatmaya neden olduğu için verim kayıplarına neden olmaktadır.

Güneydoğu Anadolu Bölgesi buğdayın gen merkezi konumundadır. Özellikle makarnalık yerel çeşitler bakımından yüksek bir çeşitliliğe sahip alanlardan birisidir. Günümüzde Adıyaman (Gölbaşı, Samsat, Besni ve Kahta ilçeleri), Diyarbakır (Çermik, Çüngüş, Ergani, Hani ve Lice ilçeleri), Mardin (Midyat ve Savur ilçeleri),
Batman (Gercüş ve Beşiri ilçeleri) ve Şırnak (Sorgül, Havrani, Menceki, Beyazi, Kunduru, Karakılçık, Bağacak) illerinin kırsal kesimlerinde bazı yerel makarnalı çeşitler hala yetiştirilmektedir (Kan ve ark., 2015). Fakat toplam buğday ekim alanı içerisinde bu çeşitlerin ekim oranı çok düşük düzeydedir. Özellikle yüksek verimli modern 1slah çeşitlerinin yaygınlaşması, teknolojik gelişimler bu çeşitlerin ileriki yıllarda yetiştiriciliğinin büyük ölçüde azalacağ1 düşünülmektedir. $\mathrm{Bu}$ nedenle bu çeşitlerin, buğday 1slah programlarında kullanılabilecek yararlı özellik ve potansiyellerinin belirlenmesi gerekmektedir. Buna ilaveten çeşitlerin yerinde korunması için hükümet desteği, pazar fiyatının yüksek tutulması, yerel çeşitlerin organik ürün kapsamına alınması gibi sürdürülebilir birtakım uygulamalara ihtiyaç duyulmaktadir.

Bu çalışmada, Güneydoğu Anadolu Bölgesi'ne ait 21 adet yerel makarnalık buğday çeşidi ve 4 adet modern ıslah çeşidinin bazı morfolojik ve fizyolojik karakterler bakımından karakterize edilmesi amaçlanmıştır.

\section{Materyal ve Yöntem}

\subsection{Materyal}

Çalışmanın bitkisel materyalini; Güneydoğu Anadolu Bölgesi'nden toplanan 21 adet yerel makarnalık buğday genotipleri (Bağacak-Mardin, Beyazi, Menceki, İskenderi, Heyidi, Minaret, Bağacak-Çınar, Devedişi, Sorgül-Şırnak, Şırnak 3, Sorgül 2, Sarıbaşak, Sarı Bursa, Şırnak 1, A-97 Yerel, Şiraslan, Kunduru, Giberunda) ile son yıllarda 1slah edilmiş standart çeşit olarak Güneydoğu Anadolu Tarımsal Araştırma Enstitüsü'nden temin edilen Sarıçanak 98, Ege Tarımsal Araştırma Enstitüsü'nden temin edilen Şölen ve Çukurova Tarımsal Araştırma Enstitüsü'nden sağlanan Ceylan-95 ve Amanos-97 çeşitleri oluşturmuştur. Araştırma; 2013-14 ve 2014-15 yetiştirme sezonunda, Mardin ili Kızıltepe ilçesi Küçükköyü çiftçi arazisinde yürütülmüştür.

Araştırma alanına ait toprakların bazı fiziksel ve kimyasal özellikleri Tablo 1'de verilmiştir.

Tablo 1. Araştırma yeri toprakların bazı fiziksel ve kimyasal özellikleri $(0-20 \mathrm{~cm})^{*}$

\begin{tabular}{lc}
\hline Toprak özelliği & Değeri \\
\hline Suya doygunluk, \% & 58 \\
pH & 7.12 \\
Elektriksel iletkenlik (EC) dS m${ }^{-1}$ & 0.013 \\
Kireç, \% & 14 \\
Organik madde, \% & 1.9 \\
Alınabilir fosfor, $\mathrm{kg} \mathrm{P}_{2} \mathrm{O}_{5} \mathrm{da}^{-1}$ & 18.3 \\
Alınabilir potasyum, $\mathrm{kg} \mathrm{K}_{2} \mathrm{O} \mathrm{da}^{-1}$ & 189 \\
\hline${ }^{*}$ : Analizler, Martest Analiz Labaratuvarı'nda yapılmıștır.
\end{tabular}


Tablo 1'den görüleceği üzere; araştırma alanı topraklarının killi-tınlı tekstürlü, hafif alkalin karakterde ve tuzluluk probleminin olmadığ 1 belirlenmiştir. Toprakların; organik madde içeriği az, kireç içeriği çok fazla, alınabilir fosfor miktarı az ve alınabilir potasyum kapsamı ise çok fazla düzeydedir (Tablo 1).

Mardin ili uzun yıllar ortalama yağış miktarı 323 mm iken, 2013-2014 yetiştirme sezonunda kaydedilen yağış miktarı 310.7 mm, 2014-2015 sezonunda ise $379.4 \mathrm{~mm}$ olmuştur. Araştırmanın yürütüldüğü yıllarda sıcaklık ve nem değerleri ise uzun yıllar ortalamasının üzerinde gerçekleşmiştir (Tablo 2).

\subsection{Yöntem}

Araştırmada tarla denemeleri, tesadüf blokları deneme desenine göre 3 tekerrürlü olarak kurulmuştur. Denemelerde, parseller boyu $6 \mathrm{~m}$, parsel eni ise $2 \mathrm{~m}\left(12 \mathrm{~m}^{2}\right)$ tutulmuş olup; her parselde 6 sıra olacak şekilde $20 \mathrm{~cm}$ sıra aralığında ekimler yapılmıştır. Ekim normu 450 tohum $\mathrm{m}^{-2}$ olup, tohum ekiminde özel parsel ekim makinası kullanılmıştır. Araştırmada ekimler yağışa bağlı şartlarda 15 Aralık tarihinde yapılmıştır.

Deneme alanına, yetiştirme yılında saf madde üzerinden $12 \mathrm{~kg} \mathrm{da}^{-1}$ azot (Üre, \% $46 \mathrm{~N}$ ) ile $10 \mathrm{~kg}$ $\mathrm{da}^{-1}$ fosforlu (Triple süper fosfat, \% 43-44 $\mathrm{P}_{2} \mathrm{O}_{5}$ ) gübre uygulanmıştır. Fosforlu gübrenin tamamı ile

Tablo 2. Araştırma yılları ve uzun yıllar (1971-2012) bazı iklim verileri (Anonim, 2016)

\begin{tabular}{|c|c|c|c|c|c|c|c|c|c|}
\hline & \multicolumn{3}{|c|}{ Nispi nem (\%) } & \multicolumn{3}{|c|}{ Ortalama sicaklık $\left({ }^{\circ} \mathrm{C}\right)$} & \multicolumn{3}{|c|}{ Toplam yağıș (mm) } \\
\hline Aylar & 2013-14 & 2014-15 & UYO & 2013-14 & 2014-15 & UYO & 2013-14 & $2014-15$ & UYO \\
\hline Ekim & 49.6 & 33.3 & 32.9 & 19.5 & 20.5 & 19.3 & 31.1 & 16.5 & 19.7 \\
\hline Kasim & 50.3 & 35.2 & 50.2 & 11.7 & 11.5 & 11.2 & 32.0 & 27.2 & 29.1 \\
\hline Aralık & 51.7 & 71.3 & 47.2 & 6.4 & 3.2 & 4.2 & 44.7 & 88.4 & 58.5 \\
\hline Ocak & 74.1 & 63.6 & 63.7 & 2.2 & 3.1 & 3.2 & 70.3 & 31.0 & 33.7 \\
\hline Şubat & 66.2 & 51.3 & 51.0 & 8.5 & 3.8 & 3.9 & 3.6 & 23.2 & 44.4 \\
\hline Mart & 59.1 & 62.5 & 62.9 & 10.0 & 9.7 & 9.0 & 80.8 & 81.7 & 79.6 \\
\hline Nisan & 41.3 & 55.7 & 55.2 & 16.8 & 13.5 & 15.2 & 27.1 & 70.9 & 84.5 \\
\hline May1s & 42.0 & 44.0 & 43.8 & 19.8 & 19.7 & 19.6 & 20.0 & 40.3 & 37.0 \\
\hline Haziran & 28.2 & 26.1 & 25.8 & 26.2 & 26.8 & 26.0 & 1.0 & 0.2 & 2.2 \\
\hline Temmuz & 22.4 & 17.0 & 16.5 & 30.6 & 32.4 & 32.1 & 0.1 & 0.0 & 0.6 \\
\hline Toplam & & & & & & & 310.7 & 379.4 & 389.3 \\
\hline Ortalama & 48.49 & 46.00 & 44.9 & 15.7 & 14.4 & 14.3 & & & \\
\hline
\end{tabular}

UYO: Uzun yıllar ortalaması

azotlu gübrenin yarısı ekim sırasında, azotun kalan diğer yarısı ise sapa kalkma döneminde verilmiştir. Çalışma kapsamında alınan gözlemler aşağıda belirtilmiştir.

Araştırmanın yürütüldüğü yıllarda tüm parsellere sarı pas (Puccinia striiformis West) üredisporları içeren karışım inokule edilmiştir. İnokulasyon kaynağ1 Yr2, Yr6, Yr6+1, Yr7, Yr9, Yr18, Yr-20, YrA, APR, Yr27, Yr28, Yr29, Yr31 ve Yr32 dayanıklılık genlerine karş1 virulent olduğu uluslararası sarı pas farklılık seti IYRAD (İnternational Yellow Rustst and Ard Differential Set) kullanılarak tespit edilmiştir. Sarı pas hastalık değerlendirilmeleri Modifiye Edilmiş Cobb Skalas1 (Peterson ve ark., 1948) kullanılarak yapılmıştır. Reaksiyon değerlendirmeleri hassas çeşit 80-90 S düzeyine ulaştığında, en az 2 defa yapılmıştır. Değerlendirmelerde pas şiddeti \% olarak; enfeksiyon R (Dayanıklı), MR (Orta dayanıklı), MS (Orta hassas) ve S (Hassas) şeklinde kaydedilmiştir.

Araştırmada hasat sırasında, parsel başlarından $0.50 \mathrm{~m}$ kenarlardan ise 1 'er sira kenar tesiri olarak atılmıştır. Tane verimi (TV), metre karede başak sayısı (MKBS), başak uzunluğu (BU), başakta tane sayısı (BTS), biyolojik verim (BV), bin tane ağırlığı (BTA) değerleri Pask ve ark. (2012)'nın bildirdikleri yönteme göre tespit edilmiştir. Çalışmada normalize edilmiş vejetasyon indeksi (NDVİ), "Green Seeker Handheld Crop Sensor Trimple" isimli optik el sensöru kullanılarak; bayrak yaprağı klorofil içeriği (SPAD), Minolta SPAD-502 cihazı ile; bitki örtüsü sıcaklığı (BÖS), taşınabilir infrared termometre (91KB JPG) kullanılarak; yaprak alan indeksi (YAI), "LAI2200 (LI-COR) plant canopy analyzer" cihazı kullanılarak, Reynolds ve ark. (2001) tarafindan bildirilen esaslara göre ölçülmüştür. SDS (Sodyum Dodesil Sülfat) sedimantasyon analizi, Anonymous (1982) standart metodu kullanılarak yapılmıştır.

İstatistiki analizler, JMP-5 SAS istatistik paket programı kullanılarak yapılmış olup, yıllara ait veriler birleşik analize tabi tutularak ANOVA analiz yöntemi uygulanmıştır. Çoklu karşılaştırma testlerinde ise LSD (Least Significant Difference Test) testi kullanılmıştır. 


\section{Bulgular ve Tartışma}

İki yıllık veriler birleşik analize tabi tutulmuş ve ANOVA analizi sonuçlarına göre yıllar ve genotipler arasındaki fark, incelenen tüm özellikler için istatistiki olarak çok önemli $(\mathrm{p}<0.01)$ bulunmuştur. Yine istatistiki analiz sonuçlara göre, genotip $\mathrm{x}$ y1l interaksiyonu ise önemsiz olarak tespit edilmiştir (Tablo 3). Aynı genotipler ile farklı yıllarda yürütülen çalışmalarda, yıllar ve genotipler arasinda istatistiki olarak önemli farklılıklar tespit edildiği ve toplam varyasyonun daha çok yıllardan kaynaklandığı bildirilmiştir (Başer ve ark., 2001; Aktaş, 2016). İncelenen özelliklerin iki yıllık ortalaması ve oluşan gruplar Tablo 4'te verilmiştir.

\subsection{Tane verimi}

İki yıllık birleştirilmiş varyans analizi sonuçlarına göre, tane verimi yönünden y1llar ve genotipler arasındaki farklılık istatistiki olarak çok önemli $\quad(p<0.01)$ bulunmuştur (Tablo 3). Genotiplerin tane verimi $201 \mathrm{~kg} \mathrm{da}^{-1}$ (A-97) ile 347 (Sarıçanak) $\mathrm{kg} \mathrm{da}^{-1}$ arasında değișmiş, ortalama tane verimi ise $259 \mathrm{~kg} \mathrm{da}^{-1}$ olarak gerçekleşmiştir. Standart olarak kullanılan çeşitler (Ceylan-98, Sarıcanak, Amanos ve Şölen) ortalaması $297 \mathrm{~kg}$ $\mathrm{da}^{-1}$ olarak kaydedilirken, en yüksek tane verimi Sarıçanak (346 kg da-1) çeşidinden elde edilmiş; Bağacak-Çınar (301 kg da $\left.{ }^{-1}\right)$, G9 (295 kg da-1), G14 (298 kg da-1) ve G24 (289 $\left.\mathrm{kg} \mathrm{da}^{-1}\right)$ yerel genotiplerinin tane verimleri standart çeşitlerin ortalamasına yakın değerlere sahip ümitvar genotipler olmuşlardır. Araştırma sonuçlarına göre; yerel genotiplerin biyolojik verimlerinin yüksek olmasına rağmen, tane verimlerinin düşük olduğu görülmektedir (Tablo 4). Ayrıca yapılan korelasyon analizinde tane verimi ile süt olum dönemi bayrak yaprak kül oranı ve gebecik dönemi NDVI değerleri arasında pozitif ve önemli bir korelasyon olduğu, YAİ ile bitki örtüsü sıcaklığı ve bayrak yaprak klorofil içeriğinin tüm dönemleri arasında negatif ve önemli bir korelasyon olduğu tespit edilmiştir (Karaman ve ark., 2014). $\mathrm{Bu}$ özelliklerin daha fazla 1slah çalışmaları ile iyileştirilmesi gerekmektedir. Birçok araştırmacı tarafından, tane veriminin yıl, lokasyon, yağış miktarı gibi birçok faktörden etkilendiği bildirilmiştir (Kılıç ve ark., 2010; Akçura ve ark., 2011).

\subsection{Metre karede başak sayısı}

Birleştirilmiş varyans analiz sonuçlarına göre, metre karedeki başak sayısı bakımından yıllar ve genotipler arasındaki farklılık istatistiki olarak çok önemli $(\mathrm{p}<0.01)$ bulunmuştur (Tablo 3$)$. İki yıllık ortalama verilere göre genotiplerin ortalama başak sayısı 242 başak $\mathrm{m}^{-2}$ olurken, standartların ortalaması 282 başak $\mathrm{m}^{-2}$, yerel çeşitlerin ortalaması ise 234 başak $\mathrm{m}^{-2}$ olarak kaydedilmiştir. Sadece G9 genotipi ise 292 başak $\mathrm{m}^{-2}$ değeri ile standart ortalamasından daha yüksek değere sahip olmuştur (Tablo 4). Metre karede başak sayısı tane verimini etkileyen en önemli özellik olduğu birçok araştırmacı tarafından açıklanmıştır (Kılıç ve ark., 2010; Akçura ve ark., 2011). Birim alandaki tane sayısının $\left(\mathrm{m}^{2}\right.$, deki başak sayısı $\mathrm{x}$ başaktaki tane sayıs1) erken kuraklık, tane ağırlığının ise geç kuraklık tarafından daha fazla sınırlandığını göstermiştir (Öztürk, 1999).

\subsection{Biyolojik verim}

Yapılan varyans analizi sonucunda, biyolojik verim üzerine genotipler ve yılların etkisi istatistiki olarak çok önemli $(\mathrm{p}<0.01)$ bulunmuştur (Tablo 3 ). İki yıllık ortalama verilere göre genotiplerin ortalama biyolojik verimi $1152 \mathrm{~kg} \mathrm{da}{ }^{-1}$ olarak gerçekleşirken, standart çeşitlerin ortalama biyolojik verimi $1125 \quad \mathrm{~kg} \quad \mathrm{da}^{-1}$ olarak kaydedilmiştir. En düşük biyolojik verim değeri $829 \mathrm{~kg} \mathrm{da}^{-1}$ ile G2 yerel genotipinden, en yüksek değer ise $1659 \mathrm{~kg} \mathrm{da}^{-1}$ ile G14 yerel genotipinden elde edilmiştir. G14 yerel genotipinin BV değeri ile Sarıçanak-98 ve Amanos-97 standart çeşitlerinin BV değerleri istatistiki açıdan birinci grubu oluşturmuş; standartların ortalama değeri $1291 \mathrm{~kg} \mathrm{da}^{-1}$ olurken, G14 (1659 kg da-1), G8 (1349 $\left.\mathrm{kg} \mathrm{da}^{-1}\right), \mathrm{G} 9\left(1339 \mathrm{~kg} \mathrm{da}^{-1}\right)$ ve G13 (1311 kg $\left.\mathrm{da}^{-1}\right)$ standart ortalamasından daha yüksek biyolojik verime sahip yerel genotipler olarak belirlenmiştir (Tablo 4). Yerel çeşitlerde ise biyolojik verimin yüksek ama hasat indeks değerinin düşük olduğu birçok araştırmacı tarafından belirtilmiştir (Moragues ve ark., 2006; Lopes ve ark., 2015). Yerel buğdaylarda biyolojik verimin yüksek olmas1, saman veriminin de yüksek olmasına neden olmakta, bu da kırsal alanlarda hayvancılık yapan çiftçiler tarafindan tercih edilmesini sağlamaktadır. Yerel genotiplerde biyolojik verimin yüksek olması bir yabani özellik olarak karşımıza çıkmakta olup, bunun 1slah çalışmaları ile iyileştirilmesi arzu edilmektedir.

\subsection{Başak uzunluğu}

Başak uzunluğu bakımından yıllar ve genotipler arasındaki farklılık istatistiki olarak çok önemli $(\mathrm{p}<0.01)$ bulunmuştur (Tablo 3$)$. İki y1llık ortalama veriler incelendiğinde genotiplerin ortalama başak uzunluğu $7.52 \mathrm{~cm}$, standartların ortalaması $8.19 \mathrm{~cm}$ olarak gerçekleşmiştir. G9, G12, G13, G14 genotipleri standartların ortalamasından daha yüksek değere sahip olurken, en yüksek başak uzunluğu standart çeşit olan Ceylan-95'ten elde edilmiştir (Tablo 4). Özellikle tahıllarda bir çeşit özelliği olan başak uzunluğu 


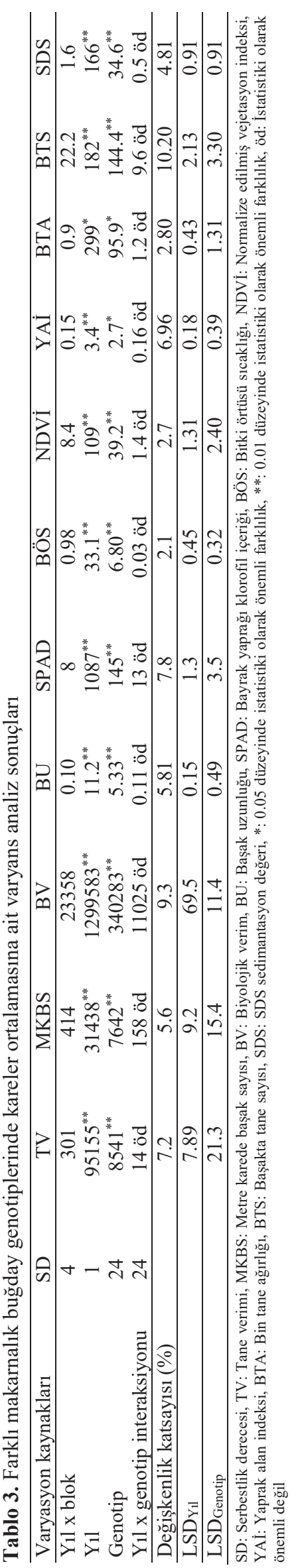




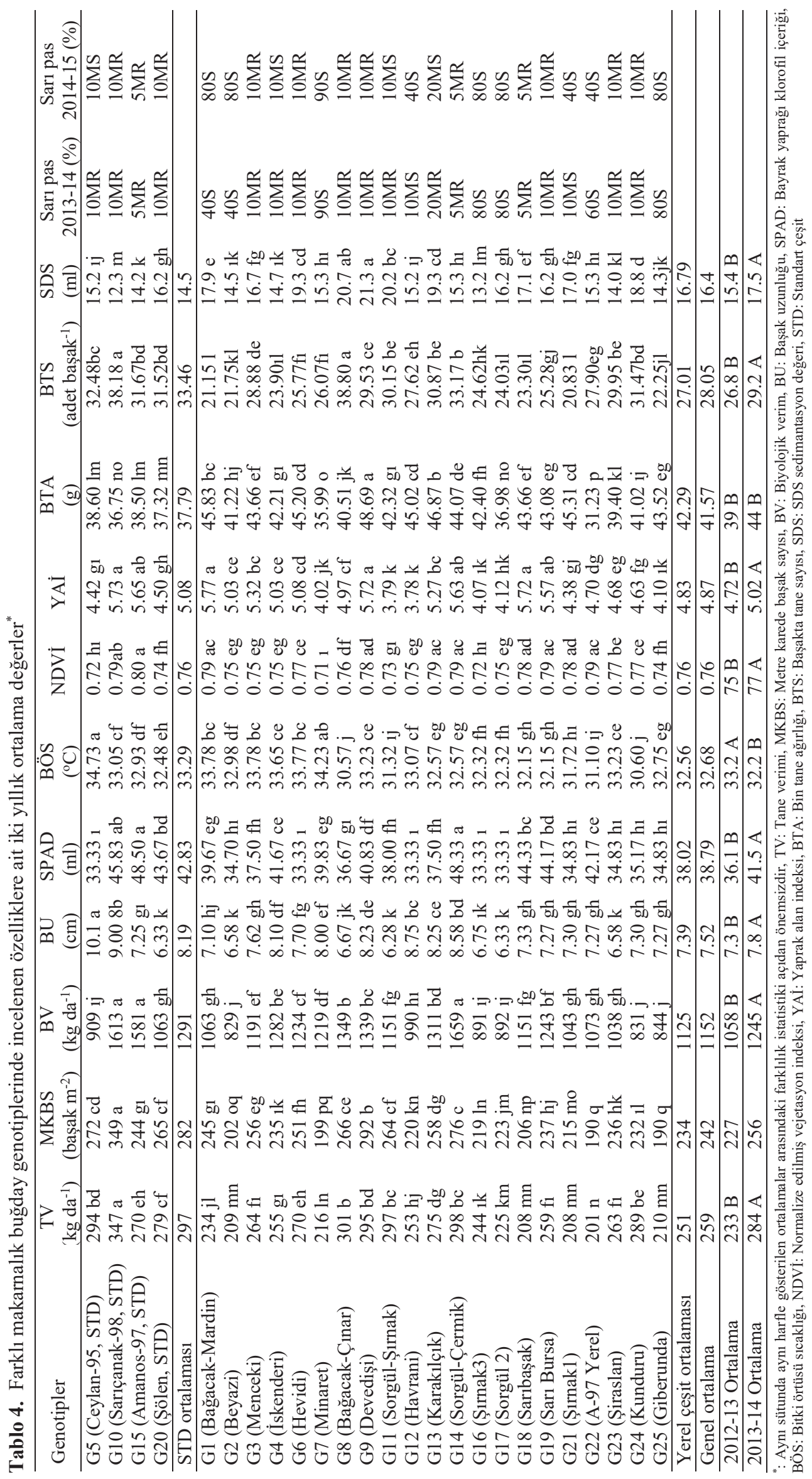


(Puri ve ark., 1982; Sönmez ve Ülker, 1998) çevresel faktörlerin etkisi altındadır.

\subsection{SDS sedimantasyon değeri}

Araştırmadan elde edilen sonuçlara göre, SDS üzerine genotipler ve yılların etkisi çok önemli bulunmuştur (Tablo 3). İki yıllık birleştirilmiş analiz sonuçlara göre, standart çeşitlerin ortalaması $14.5 \mathrm{ml}$ iken, standartlar içerisinde en yüksek değer $16.2 \mathrm{ml}$ ile G20'den elde edilmiş, yerel çeşitlerin ortalaması $16.8 \mathrm{ml}$ olarak kaydedilmiştir. Araştırmada incelenen tüm genotipler içerisinde en yüksek SDS değeri $21.3 \mathrm{ml}$ ile $\mathrm{G} 9$ yerel genotipinden elde edilmiş olup, standart çeşitlerden daha yüksek SDS değeri göstermiştir. Yerel genotipler içerisinde G9'u; G8 (20.7 ml), G11 (20.2 ml), G13 (19.3 ml), G6 (19.3 ml), G24 $(18.8 \mathrm{ml})$ ve $\mathrm{G} 1$ (17.9 ml) genotipleri izlemiştir (Tablo 4). Bu sonuçlar, yerel buğday çeşitlerinin gluten kalitesi bakımından modern 1slah çeşitlerinden daha üstün bir özelliğe sahip olduklarını göstermektedir. Özellikle SDS sedimantasyon değeri makarnalık buğday türünde gluten kalitesi konusunda fikir veren bir analizdir. Sedimantasyon değeri farklı çevre, iklim, toprak gibi faktörlerden etkilenmekle beraber, protein oranı ve diğer kalite parametrelerine oranla bu etkilenme daha az ve kalıtım etkisi bu parametre için daha fazladır (Atlı ve Koçak, 2004).

\subsection{Normalize edilmiş vejetasyon indeksi (NDVİ) değeri}

Ortalama NDVİ değeri üzerine genotipler ve y1lların etkisi çok önemli $(\mathrm{p}<0.01)$ bulunmuştur (Tablo 3). Normalize edilmiş vejetasyon indeksi çeşitler ve genotiplerde ortalama 0.76 olarak gerçekleşirken, en düşük değer 0.71 ile G7 çeşidinden, en yüksek değer ise 0.80 ile standart çeşit olan Amanos'dan elde edilmiştir (Tablo 4). Buğdayın kardeşlenme ve tane doldurma dönemlerinde bitkinin toprağı kapatma oranının ve toplam biyolojik verimin tahmininde kullanılan NDVİ değeri, son yıllarda ıslahçılar ve gelişmiş bir çok ülkede ise çiftçiler tarafından kullanılmaktadır (Lopes ve ark., 2015). Tane doldurma dönemindeki NDVİ değerinin biyolojik verim ve tane verimi ile ilişkisinin daha yüksek olduğu belirtilmektedir (Karaman, 2017; Lopes ve ark., 2015).

\subsection{Klorofil değeri (SPAD değeri)}

Tablo 3'te görüldüğü gibi iki y1llık ortalama veriler incelendiğinde, klorofil değeri (SPAD) üzerine y1llar ve genotiplerin etkisi istatistiki açıdan çok önemli $(\mathrm{p}<0.01)$ bulunmuştur. Araştırma sonucunda elde edilen en yüksek SPAD değer, 48.50 ile Amanos standart çeşidinden elde edilirken, standartların ortalaması 42.83 olarak kaydedilmiştir. G14 (48.33) yerel genotipinin SPAD değeri Amanos çeşidi ile istatistiki olarak birinci grubu oluşturmuş olup; G14 (48.33), G18 (44.33) ve G19 (44.17) yerel buğday çeşitleri standartların ortalamasından daha yüksek SPAD değerine sahip genotipler olmuştur (Tablo 4). Kuraklık ve tane doldurma döneminde yüksek sıcaklıkların oluştuğu alanlarda, buğday bitkisinin bayrak yaprağında klorofil miktarı azalırken, stomaların işlevi de büyük ölçüde düşmektedir (Reynolds ve ark., 2001). Buğday genotipleri bu stres koşullarına farklı tepkiler göstermekte, SPAD değeri yüksek olan genotipler genel olarak bu stres koşullarına uyum sağlayabilmektedir (Reynolds ve ark., 2001).

Fischer (1996) yaprakların klorofil içeriğinin genotipin fotosentetik kapasitelerini yansıttığını belirtmiştir. Yadava (1986) ise, SPAD değerleri ile okuma anında yaprakların içerdiği klorofil miktarları arasında linear bir ilişkinin bulunduğunu bildirmiştir. $\mathrm{Bu}$ sistem yaprakların sahip olduğu yeşil rengin ölçülmesi yolu ile dolaylı olarak klorofil miktarı ve azot içeriğinin belirlenmesi esasına dayanmaktadır. Bitkideki klorofil yoğunluğu ile biyolojik verim arasında pozitif bir ilişki bulunmaktadır. Benzer bir araştırmada Dönmez ve ark. (2008) çevresel şartlardan etkilenen bir özellik olan klorofil yoğunluğunun, genellikle besin maddelerinin eksikliğinden dolayı bitkide renk açılması veya sararma şeklinde ortaya çıktığını belirtmektedirler. Çalışmada kullanılan SPAD, yaprak rengi açık yeşil olan çeşitlerin klorofil içeriği değerlerinin genellikle düşük olduğunu göstermiştir.

\subsection{Bin tane ağırlığı}

İki yıllık birleştirilmiş varyans analiz sonuçlarına göre, bin tane ağırlığı üzerine genotiplerin ve çeşitlerin etkisi istatistiki yönden önemli $\quad(p<0.05)$ bulunmuştur (Tablo 3). Standartların ortalama bin tane ağırlı̆̆ $37.79 \mathrm{~g}$ olurken, yerel çeşitlerin ortalaması ise $42.29 \mathrm{~g}$ olarak kaydedilmiştir (Tablo 4). Bu sonuç, yerel buğday çeşitlerinin bin tane ağırlığı bakımından standart olarak kullanılan modern sslah çeşitlerine kıyasla bariz bir üstünlüğünün olduğunu ve iri ve bin tanesi ağırlı̆̆ yüksek olan çeşit geliştirmede bu yerel çeşitlerin kullanılmasının yararlı olacağını göstermektedir. En yüksek bin tane ağırlığı, 48.69 $\mathrm{g}$ ile yerel olan Devedişi çeşidinden elde edilirken, en düşük değer ise yerel G22'den elde edilmiştir (Tablo 4). Bin tane ağırlığının yüksek olması, makarnalık buğdaylarda irmik verimini artmasını sağlamaktadır. Yerel buğday çeşitlerinin iriliği ve bin tane ağırlığı genel olarak daha yüksek olup, modern buğday islah programlarındaki 
çalışmalarla geliştirilen çeşitlerde, başakta tane sayısı artarken tane iriliği ve bin tane ağırlığında ise düşüşler olmuştur (Lopes ve ark., 2015).

\subsection{Yaprak alan indeksi (YAİ)}

Tablo 3'te görüldüğü üzere, YAİ üzerine yıllar $(p<0.01)$ ve genotiplerin $(p<0.05)$ etkisi önemli bulunmuştur. YAİ değeri 3.78 (G12) ile 5.73 (Sarıçanak) arasında değişmiş, standartların ortalama YAİ değeri 5.08 olurken, G3, G6, G9, G13, G14, G18, G19 yerel çeşitleri standart ortalamasından daha yüksek değerlere sahip olmuşlardır (Tablo 4).

Son yıllarda, birçok diğer parametre gibi YAİ değerleri de optik alan ölçücü cihazlar ve spektral yansıma yöntemleriyle hesaplanabilmektedir. Elliott ve Regan, (1993) tarafından yürütülen bir çalışmada; biyolojik verim ağırlıkları ve YAİ değerleri arasında tüm vejetasyon süresi boyunca elde edilen sonuçlara göre korelasyonun önemsiz $(\mathrm{r}=0.01)$ olduğunu, oysa YAİ değerlerinin 3-4 arasında olduğu daha kisa bir dönemde ele alındığında biyolojik verim ağırlığ 1 (kuru madde) ile YAİ arasında önemli bir korelasyon $(r=0.73)$ olduğunu belirtmektedir.

\subsection{Başakta tane sayısı}

Araştırma sonuçlarına göre çeşitler ve genotipler arasında başakta tane sayısı bakımından istatistiki açıdan önemli $(p<0.01)$ düzeyde bir fark oluşmuştur (Tablo 3). Buna göre genotiplerin ortalama başakta tane sayısı 28.05 adet/başak olurken, standart çeşitlerde bu ortalama 33.46 adet/başak, yerel çeșitlerde ise 27.01 adet/başak olarak tespit edilmiştir (Tablo 4). Elde edilen sonuçlara göre genotiplerin başak uzunluğu çeşitlere göre kısa olmasına rağmen bin dane ağırlığı daha yüksek olmuştur. Özellikle başakta tane sayısı tane verimine olumlu etki yapan bir karakter olup, modern ıslah çalışmalarıyla geliştirilen çeşitlerde başakta tane sayısı yüksek fakat tane iriliği ve bin tane düşük olmaktadır
(Lopes ve ark., 2015).

\subsection{Bitki örtüsü sıcaklığı (BÖS)}

İki yıllık birleştirilmiş varyans analiz sonuçlarına göre; yıllar ve genotiplerin bitki örtü sıcaklığı üzerine etkisi çok önemli $(p<0.01)$ olmuştur (Tablo 3). İki yıllık birleşik analiz sonuçlarına göre en yüksek BÖS $34.73{ }^{\circ} \mathrm{C}$ ile G5 ve en düşük BÖS değeri ise $30.57{ }^{\circ} \mathrm{C}$ ile G8'den elde edilmiştir. Standartların ortalama BÖS değeri $33.30{ }^{\circ} \mathrm{C}$ olurken, çok sayıda yerel buğday çeşidi daha düşük BÖS değerine sahip olmuştur (Tablo 4). Yüksek sıcaklığın birçok tarımsal üründe olduğu gibi buğdayda da verim ve kalitede önemli düşüşlere neden olduğu bilinmektedir (Gibson ve Paulsen, 1999; Başer ve ark., 2001). Özellikle Güneydoğu Anadolu Bölgesi’nde çiçeklenme ve daha çok tane dolum döneminde $35-40{ }^{\circ} \mathrm{C}^{\prime}$ lere varan yüksek sicaklıklardan sonra buğdayda oluşan verim ve kalite kayıpları bölge çiftçisinin yıllardır şikâyet konusu olmuştur.

\subsection{Sarı pas}

Her iki yılda da yapay olarak yapılan pas inokulasyonunda da hastalı oluşumu gerçekleşmiştir. Her iki sezonda da \% MR (Orta dayanıklı) ile 90S arasında değişmiş, genel olarak hassas olan çeşitler daha düşük tane verimine sahip olmuşlardır (Tablo 4). Benzer sonuçlar Aktaş (2014) tarafından belirtilmiş olup, yerel buğday çeşitlerinin yüz yıllar boyunca aynı çevrede yetiştirilmesi bazı sarı pas patotiplerine karşı hassas hale geldiği, başka bir ifade ile bu patotiplerin bu yerel buğdayların savunma mekanizmaları üzerinde uzmanlaştığı, fakat hastalı seyrinin bayrak yaprağ gelişiminin yavaş olduğu bildirilmektedir (Ali ve ark., 2007; Safavi, 2015).

\subsection{Korelasyon analizi sonuçları}

Makarnalık buğday genotiplerine ait incelenen tarımsal özellikler arasındaki korelasyon katsayıları Tablo 5'te verilmiştir. Yapılan

Tablo 5. Farklı buğday genotiplerinde, incelenen tarımsal özellikler arasındaki korelasyon katsayıları

\begin{tabular}{|c|c|c|c|c|c|c|c|c|c|c|}
\hline Özellikler & TV & MKBS & BV & $\mathrm{BU}$ & SPAD & BÖS & NDVİ & YAİ & BTA & BTS \\
\hline TV & 1 & & & & & & & & & \\
\hline MKBS & $0.92^{* *}$ & 1 & & & & & & & & \\
\hline BV & $0.54^{* *}$ & $0.62^{* *}$ & 1 & & & & & & & \\
\hline BU & 0.37 & $0.41^{*}$ & 0.33 & 1 & & & & & & \\
\hline SPAD & 0.25 & 0.34 & $0.76^{* *}$ & 0.12 & 1 & & & & & \\
\hline BÖS & 0.29 & 0.38 & 0.28 & $0.47^{*}$ & 0.04 & 1 & & & & \\
\hline NDVİ & 0.31 & -0.30 & 0.31 & -0.09 & 0.37 & -0.14 & 1 & & & \\
\hline YAI & -0.10 & -0.01 & $0.46^{*}$ & 0.08 & $0.51^{* *}$ & 0.29 & $0.76^{* *}$ & 1 & & \\
\hline BTA & 0.08 & 0.12 & 0.06 & 0.12 & -0.17 & 0.12 & 0.17 & 0.24 & 1 & \\
\hline BTS & $0.85^{* *}$ & $0.72^{* *}$ & $0.54^{* *}$ & 0.30 & 0.30 & 0.14 & -0.19 & -0.08 & -0.27 & 1 \\
\hline SDS & -0.20 & 0.17 & 0.06 & -0.16 & -0.15 & 0.16 & 0.30 & 0.25 & $0.47^{*}$ & 0.12 \\
\hline
\end{tabular}

TV: Tane verimi, MKBS: Metre karede başak sayısı, BV: Biyolojik verim, BU: Başak uzunluğu, SPAD: Bayrak yaprağı klorofil içeriği, BÖS: Bitki örtüsü sıcaklığı, NDVİ: Normalize edilmiş vejetasyon indeksi, YAİ: Yaprak alan indeksi, BTA: Bin tane ağırlığı, BTS: Başakta tane sayısı, SDS: SDS sedimantasyon değeri, *: 0.05 düzeyinde istatistiki olarak önemli farkl1lık, **: 0.01 düzeyinde istatistiki olarak önemli farkll11k 
korelasyon analizi sonucu tane verimi ile birim katsayıları Tablo 5'te verilmiştir. Yapılan korelasyon analizi sonucu tane verimi ile birim alanda başak sayısı $\left(0.92^{* *}\right)$, başakta tane sayısı $\left(0.85^{* *}\right)$ ve biyolojik verim $\left(0.54^{* *}\right)$ arasında istatistiki olarak çok önemli pozitif korelasyon olduğu tespit edilmiştir. SPAD ile YAİ arasında $\left(0.51^{* *}\right)$, NDVİ ile YAİ $\left(0.76^{* *}\right)$ arasında, BU ile BÖS arasinda $\left(0.47^{*}\right)$, BTA ile $\operatorname{SDS}\left(0.47^{*}\right)$ arasında; BV ile YAI $\left(0.46^{*}\right)$ arasında istatistiki olarak önemli ve yüksek korelasyon elde edilmiştir (Tablo 5). Birim alanda başak sayısı ve başakta tane sayısının tane verimini etkileyen karakterler olduğu birçok araştırmacı tarafından belirtilmiştir (Sönmez ve Ülker, 1998; Kılıç ve ark., 2010). NDVI, YAİ ve biyolojik verim arasında yüksek korelasyonlar tespit edilirken, bu karakterlerin dolaylı olarak tane verimine katkı yaptığı bazı araştırmacılar tarafindan bildirilmektedir (Reynolds ve ark., 2001; Karaman, 2017).

\section{Sonuçlar}

$\mathrm{Bu}$ çalışma sonucunda Güneydoğu Anadolu Bölgesi'ne has olan yerel makarnalık buğday çeşitlerinin; tane verimi, metrekare başak sayısı, biyolojik verim, başak uzunluğu, SPAD değeri gibi özellikler bakımından modern 1slah genotipleri (Ceylan-98, Sarıcanak, Amanos ve Şölen)'ne göre daha üstün özelliklere sahip olduğu ve modern genotiplerin bu özelliklerinin iyileştirilmesi noktasında buğday 1slah programlarına ihtiyaç olduğu sonucuna varılmıştır. Özellikle tane verimi bakımından Sorgul-Çermik ve Bağacak-Çınar genotiplerinin ümitvar olduğu düşünülmektedir. Ayrıca, NDVI, SPAD, YAİ gibi gibi fizyolojik parametrelerin verim tahmininde kullanılabileceği ve bu konuda mutlaka daha fazla çalışmalar yapılması gerektiği sonucuna varılmıştır.

\section{Kaynaklar}

Akçura, M., Partigoç, F., Kaya, Y., 2011. Evaluating of drought stres stolerance based on selection indices in Turkish bread wheatland races. The Journal of Animal and Plant Sciences, 21(4): 700-709.

Aktaş, H., 2014. Investigation of quality stability and micro elements content of some bread wheat varieties in southeast Anatolia region conditions. Phd thesis, Mustafa Kemal University, Field Crop Department, Hatay.

Aktaş, H., 2016. Drought tolerance indices of selected landraces and bread wheat (Triticum aestivum L.) genotypes derived from synthetic wheats. Applied Ecology and Environmental Research, 14(4): 177189.
Anonim, 2016. Mardin Meteoroloji Bölge Müdürlüğü Kayıtları. (https://www.mgm.gov.tr/), (Erişim tarihi: 01.01.2016).

Anonymous, 1982. Standard methods of the international association for cereal science and technology, International Association for Cereal Science and Technology, Vienna, Austria Standard Method 115/1. Vienna, Austria: ICC. (https://www. icc.or.at/publications/icc-standards/standards-overvi ew/115-1-method-for-using-the-brabender-farinogra ph), (Erişim tarihi: 01.03.2019).

Ali, S., Shah, S.J.A., İbrahim, M., 2007. Assessment of wheat breeding lines for slow yellow rusting (Puccinia striiformis West. tritici). Pakistan Journal Biological Science, 10(19): 3440-3444.

Atlı, A., Koçak, N., 2004. Islah programlarında ekmeklik buğday kalitesinin farklı sedimentasyon testleri ile tahmini. Harran Üniversitesi Ziraat Fakültesi Dergisi, 8(2): 156-164.

Baloch, F.S., Alsaleh, A., Shahid, M.Q., Çiftçi, V., De Miera, L.E.S., Aasim, M., Nadeem, M.A., Aktaş, H., Özkan, H., Hatipoğlu, R., 2017. A whole genome DArTseq and SNP analysis for genetic diversity assessment in durum wheat from central fertile crescent. Journal Plos, 12(1): 1-10.

Başer, N., Öztürk, İ., Avc1, R., Kahraman, T., 2001. Trakya bölgesi'nde yetiştirilen buğday çeşitlerinin verim, kalite ve diğer bazı özellikleri ile buğday tarımının önemli sorunları. Türkiye IV. Tarla Bitkileri Kongresi, 17-21 Eylül, Tekirdağ, s. 1: 6368.

Chen, X.M., 2005. Epidemiology and control of stripe rust on wheat (Puccinia striiformisf sp. Tritici) on wheat. Canadian Journal Plant Pathol, 27(3): 314337.

Dönmez, Ö., Aydemir, T., Aktaş, B., 2008. Arpada Çeşit Tanımlaması. Tohumluk Tescil ve Sertifikasyon Merkezi Yayınları, Ankara.

Elliott, G.A., Regan, K.L., 1993. Use of reflectance measurements to estimate early cereal biomass production on sand plain soils. Australian Journal of Experimental Agriculture, 33(2): 179-183.

Fischer, R.A., 1996. Wheat physiology at CIMMYT and raising the yield plateau. In: MP. Reynolds, S. Rajaram, A. McNab (Eds.), Increasing yield potential in wheat: Breaking the barriers. Mexico: CIMMYT, pp. 195-203.

Heun, M., Schafer-Pregl, R., Klawan, D., Castagna, R., Accerbi, M., Borghi, B., Salamini, F., 1997. Site of einkorn wheat domestication identified by DNA finger printing. Science, 278(5341): 1312-1314.

Gibson, L.R., Paulsen, G.M., 1999. Yield components of wheat grown under high temperature stres during reproductive growth. Crop Science, 39(6): 18411846.

Kan, M., Küçükçongar, M., Keser, M., Morgounov, A., Muminjanov, H., Özdemir, F., Qualset, C., 2015. Wheat landraces in farmers' fields in Turkey. 
National Survey, Collection and Conservation, 2009-2014, pp. 178.

Karaman, M., 2017. Makarnalık buğdayda fizyolojik ve morfolojik parametrelerin verim ve kalite ile olan ilișkisinin belirlenmesi. Doktora tezi, Dicle Üniversitesi Fen Bilimleri Enstitüsü, Diyarbakır.

Karaman, M., Akınc1, C., Yıldırım, M., 2014. Bazı ekmeklik buğday çeşitlerinde fizyolojik parametreler ile tane verimi arasındaki ilişkinin araştırılması. Trakya University Journal of Natural Sciences, 15(1): 41-46.

K1lıç, H., Akçura, M., Aktaş, H., 2010. Assessment of parametric and non-parametric methods for selecting stable and adapted durum wheat genotypes in multienvironments. Notulae Botanicae Horti Agrobotanici Cluj-Napoca; Cluj-Napoca, 38(3): 271-279.

Lopes, M., El-Basyoni, L., Baenziger, P.S., Singh, S., Royo, C., Özbek, K., 2015. Exploiting genetic diversity from landraces in wheat breeding for adaptation to climate change. Journal of Experimental Botany, 66(12): 3477-3486.

Moragues, M., García Del Moral, L.F., Moralejo, M., Royo, C., 2006. Yield formation strategies of durum wheat landraces with distinct pattern of dispersal with in the Mediterranean basin: I. Yield components. Field Crops Research, 95(2-3): 194205.

Özkan, H., Willcox, G., Graner, A., Salamini, F., Kilian, B., 2011. Geographic distribution and domestication of wild emmer wheat (Triticum dicoccoides). Genetic Resources and Crop Evoluation, 58(1): 1153.
Öztürk, A., 1999. Kuraklığın kışlık buğdayın gelişmesi ve verimine etkisi. Turkish Journal of Agriculture and Forestry, 23(1): 531-540.

Pask, A.J.D., Pietragalla, J., Mullan, D.M., Reynolds, MP., 2012. Physiological Breeding II: A Field Guide to Wheat Phenotyping. A. Pask, D. Mullan, M. Reynolds (Eds.), Grain yield and yield components, CIMMYT, Mexico City, Mexico, pp. 95-106.

Peterson, R.F., Campbell, A.B., Hannah, A.E., 1948. A diagrammatic scale for estimating rustin tensity on leaves ands tems of cereal. Canadian Journal of Research, 26(5): 496-500.

Puri, Y.P., Qualset, C.O., Willams, W.A., 1982 Evolation of yield component as slection criteria in barley. Crop Science, 22(3): 927-931.

Reynolds, M.P., Nagarajan, S., Razzaque, M.A., Ageeb, O.A.A., 2001. Heat tolerance. In M.P. Reynolds, I. Ortiz-Monasterio, A. McNab (Eds.), Application of Physiology in Wheat Breeding, CIMMYT, Mexico, pp. 124-136.

Safavi, S.A., 2015. Effects of yellow rust on yield of race specific and slow rusting resistant wheat genotypes. Journal Crop Protection, 4(3): 395-408.

Sönmez, F., Ülker, M., 1998. Van yöresinde serin iklim tahıllarının durumu. Doğu Anadolu Tarım Kongresi, 14-18 Eylül, Van, s. 147-156.

Wan, A., Zhao, Z., Chen, X.M., 2004. Wheat stripe rust epidemic and virulence of (Puccinia striiformis f. sp. Tritici) China in 2002. Plant Disease, 88(8): 896904.

Yadava, U.L., 1986. A rapid and non-destructive method to determine chlorophyll in intact leaves. Horticulture Science, 21(1): 1449-1450. 